\title{
EERS DIE JODE, DAN DIE GRIEKE: PAULUS AS SENDELING
}

\author{
Cilliers Breytenbach \\ Humboldt-Universität zu Berlin \\ Ou \& Nuwe Testament \\ Universiteit Stellenbosch
}

\begin{abstract}
In this essay Paul's major theological decisions determining the course of his mission are explained. He adhered to principles that the faith of the individual is fundamental and that congregations are constituted beyond the boundaries marked by gender, kinfolk, ethnicity and cultural identity. Thereby Paul had a permanent influence on the identity of Christianity.
\end{abstract}

Key Words: Paul, Mission, Christian Identity

In hierdie voëlvlug oor die eerste jare van die Christelike sending wil ek op Paulus konsentreer en vra watter rol hy by die insluiting van Griekssprekende nie-Joodse gelowiges in die vroeë Christendom gespeel het. Hoewel belangrike episodes uit sy sendingwerk in die jare veertig van die eerste eeu vanuit Antiogië, Masedonië en Korinte as voorbeelde dien, gaan dit hier om die geheelbeeld en nie om detail-probleme nie. ${ }^{1}$

\section{Aanloop en eukumeniese grondbeginsels}

Damaskus: Paulus se aanstelling as bemiddelaar van die evangelie

Paulus was nie altyd 'n Christen nie. In die gebruiklike sin van die woord was hy eintlik nooit 'n Christen nie. Paulus is as 'n Jood gebore (2 Kor 11:22). Sy Joodse naam was Saul. Omdat hy in 'n Griekssprekende omgewing in Tarsus in die landstreek Silisië groot geword het, is hy Paulus genoem, omdat dit baie soos die Hebreeuse Saul(us) klink. Soos die eerste koning van Israel, Saul, na wie hy vernoem is, was ook Paulus uit die stam van Benjamin. Toe hy agt dae oud was, het sy ouers hom laat besny (Fil 3:5). As 'n jong man was Paulus godsdienstig baie toegewyd - meer as die ander jong manne van sy ouderdom. Hy het hom vir die toepassing van die wet van Moses beywer en geprobeer om so te lewe soos sy voorvaders die wet geïnterpreteer het (Gal 1:13-14). Al het Paulus as 'n Jood êrens in die middel van sy lewe begin om Jesus Christus as die Here van sy lewe te dien, het hy nooit opgehou om 'n Jood te wees nie (Rom 9:1-2).

Tog is daar 'n verskil tussen Paulus en die ander Jode. Saam met Jode soos Simon Petrus, Johannes en Jakobus het hy geglo dat Jesus, die Jood Jesuha uit die klein gehuggie Nasaret in Galilia (Mark 6:1-3), die een wat soos 'n slaaf wat gedros het of 'n terroris op bevel van die Romeinse prefek van Judea, Pontius Pilatus met 'n gesel voos geslaan en toe buite Jerusalem aan 'n kruis vasgespyker is en toe versmoor het (Mark 15) - saam met hierdie eerste volgelinge van Jesus het Paulus geglo dat God die dood gemartelde Jesus uit

\footnotetext{
Die artikel is die teks van die jaarlikse FC Fenshamgedenklesing wat op 28 Augustus 2007 op Stellenbosch gelewer is. Die voetnotas is tot die minimum beperk. Vir 'n resente en maklik leesbare weergawe van Paulus se lewe, vgl. Schnelle, Udo. Apostle Paul: His Life and Theology. Grand Rapids: Baker, 2005.
} 
die dood opgewek het (Rom 10:9). Paulus sê hy het die Here gesien (1 Kor 9:1), Christus het aan hom verskyn (1 Kor 15:8) en aan hom 'n opdrag gegee. Hierdie ontmoeting oppad na Damaskus (vgl. Gal 1:17b; Hand 9:1-9) het Paulus se lewe ingrypend verander. Dit het egter nie sy etnisiteit verander nie. Hy het 'n Jood gebly, maar een wat op grond van sy geloof dat God die gekruisigde Christus lewendig gemaak het, Jesus as sy Here en meester begin dien het.

Die opdrag aan Paulus het daarin bestaan dat hy vir sover hy gaan, die goeie nuus aan die mense moet vertel, dat God deur die dood en opwekking van Jesus Christus mense van die gevolge van hulle oortreding van die wet verlos, en so uit die dood red. Hy moes die mense oproep om op die belofte te vertrou.

\section{Die begin van die verkondiging aan heidene in Silisië en Sirië}

Paulus het sy ervaring oppad na Damaskus as genade en goedgunstelikheid van God teenoor hom geïnterpreteer (vgl. Gal 1:15; 2:9; 1 Kor 3:10; 7:25; 15:10; 2 Kor 4:1, Rom $1: 5 ; 15: 14-15$ ) wat hom 'n apostel, dit beteken 'n uitgestuurde of sendeling, gemaak het. Voor Damaskus het Paulus hom so beywer vir die wet, dat hy naarstiglik geprobeer het om God se uitverkorenes, die mense wat in Jerusalem en Judea saamgekom het om Jesus as Messias en Here te vereer, te vervolg. Hy het inderdaad probeer om hulle uit te roei (Gal 1:14-16). Trouens, hy was oppad na Damaskus om die volgelinge van Jesus daar gevange te neem. Juis hý word toe gekies om God se evangelie, die vreugdeboodskap dat God uit die goddelose wetsoortreder 'n vrygesproke nuwe mens maak, te verkondig. Paulus word getuie vir die boodskap wat hy wou uitroei (Gal 1:23).

Hy laat nie veel gras onder sy voete groei nie. Nadat hy vir 'n tyd in Arabië die evangelie verkondig het, ${ }^{2}$ gaan hy op 'n kort besoek na Petrus in Jerusalem, vanwaar hy na sy geboortestad, Tarsus, vertrek (Gal 1:17-21) om daar die evangelie te verkondig (vgl. Hand 15:41). Ongelukkig weet ons eintlik maar min van hierdie donker jare in Paulus se lewe, ${ }^{3}$ maar 'n mens kan daarvan uitgaan dat Paulus van die begin af die evangelie aan Jode soos hyself, maar veral aan nie-Jode, verkondig het. Hy sê immers self - by implikasie met verwysing na die gebeure oppad na Damaskus - dat God sy Seun aan hom bekend gemaak het, sodat hy die blye boodskap oor hom aan die nasies, die nie-Jode, kan verkondig (Gal 1:16).

In die stad Antiogië in Sirië het Griekssprekende Jode wat in Jesus geglo het, begin om die evangelie nie net aan Jode nie, maar ook aan Griekssprekende nie-Jode te verkondig (Hand 11:19-20). Barnabas, 'n belangrike persoon in die vroeë kerk, het Paulus in Tarsus laat haal en na Antiogië laat kom (Hand 11:21). Hy doen dit waarskynlik omdat Paulus reeds in daardie stadium die blye boodskap aan die nie-Jode verkondig het en dus 'n soortgelyke bediening in Antiogië kon voortsit.

Met Barnabas en Paulus se hulp groei die gemeente in Antiogië vinnig. Daar sluit binne 'n jaar so baie nie-Jode by die gemeente aan dat die inwoners van die stad, om die gemeente van die Jode te onderskei, hulle Christianoi, d.w.s. mense wat Christus se volgelinge is, Christene, noem (Hand 11:26).

\footnotetext{
Die sending van Paulus word net in Gal 1:17 genoem. Vgl. Martin Hengel/Anna-Maria Schwemer, Paul between Damascus and Antioch: The Unknown Years, London: SCM 1997.

Vgl. Hengel/Schwemer, Paul.
} 


\section{Die eerste sending: Barnabas en Paulus op Siprus en in Galasië}

Tot dusver is daar nog nie werklik sprake van sending in die moderne sin van die woord nie. Die Joodse volgelinge van Christus het bloot die blye boodskap aan die Jode in hulle omgewing verkondig en so nuwe lede aangetrek. In Antiogië het hulle ook begin om die evangelie aan die Grieke te verkondig. Die eerste sistematiese Christelike sénding het eers begin toe die gemeente in Antiogië vir Barnabas en Paulus as apostels uítgestuur het om die woord op die eiland Siprus te gaan verkondig (Hand 13:4 e.v.). ${ }^{4}$ Dit het egter nie hier net om sending aan die nie-Jode gegaan nie. Barnabas het immers van Siprus af gekom. Vanselfsprekend dat hulle die blye boodskap ook aan Barnabas se Joodse familielede in die sinagoge verkondig het. Met die hulp van die Romeinse pro-konsul op Siprus, Sergius Paul(l)us het Paulus, 'n Romeinse burger, en Barnabas na die provinsie Galasië in KleinAsië vertrek om die evangelie daar binne die Romeine militêre kolonies in Antiogië aan die Psidiese grens (Antiochia Colonia Caesarea), in Ikonium (Colonia Iulia Augusta Iconium) en in Liste (Colonia Iulia Felix Gemina Lustra), te verkondig (Hand 13:7, 13 e.v.). Nou word dit toenemend sending onder die nie-Jode.

Terug in Antiogië in Sirië vertel Barnabas en Paulus dat God 'n deur vir die nasies, aldus vir die nie-Jode, geopen het sodat hulle kan glo (Hand 14:27). Die vraag onstaan onmidddelik: Na watter 'deur' verwys hy? Hoe glo die nie-Jode, en hoe kry hulle toegang tot die geloofsgemeenskap?

Tot dusver was die volgelinge van Christus 'n beweging binne die Jodedom. Joodse volgelinge van Jesus wat in sy opstanding geglo het, het hom as Messias en Here vereer, maar hulle het Jode gebly en steeds binne die gemeenskap van die sinagoge geleef. Hoe gaan die nie-Jode opgeneem word? Al word die party van Christus in Antiogië as groep Christene genoem en van die Jode in die stad onderskei, is daar grense tussen Jode binne en die meerderheid Jode buite die Christusparty. As Jode het hulle veel in gemeen, die besnydenis, die verbond, 'n leefwyse beskerm deur die wet as 'n ringmuur om hulle. Weekliks onderhou hulle die Sabbat, jaarliks vier hulle verskeie feeste, hulle het vaste onderlinge familiebande, ens. Slegs 'n minderheid van hulle het aan die Christusparty behoort. Maar die Joodse en nie-Joodse Christene het ook veel in gemeen. Alle Jode en nie-Jode wat aan die Christusparty behoort het, was gedoop en het saam nagmaal gevier, maar hulle het uit uiteenlopende kulturele en religieuse agtergronde gekom. ${ }^{5}$ Die vraag is: Hoe het die vroeë Christendom hierdie situasie hanteer?

\section{Die Jerusalemse kompromie}

Die eerste gemeente, ofte wel die moedergemeente, was die gemeente in Jerusalem. In die vroeë jare is die gemeente deur drie persone gedra: Petrus, die leier van die twaalf, Johannes, en Jakobus die broer van Jesus (Gal 2:9). Hulle was besorgd oor die inlywing van die nie-Joodse gelowiges in die gemeente van Antiogië en elders. Beteken dit nou dat die Jode wat in Jesus as Christus en Here glo, saam met die nie-Jode in die gemeentes moet leef? Moes hulle nou saam met sulke onbesnede heidene wat nie volgens die wet leef nie, wat nie die Sabbat hou nie, aan een nagmaalstafel sit? Moes hulle byvoorbeeld kos eet wat deur vroue voorberei is wat hulle nie aan die Joodse reinheidsrituele na hulle maandstonde steur nie? Moes hulle assosieer met mans wat aan besigheidsetes deelgeneem het waar onrein vleis geëet is? Sou dit nie eerder korrek wees dat sulke Grieke en ander nasies eers

\footnotetext{
Vgl. Cilliers. Breytenbach, Paulus und Barnabas in der Provinz Galatien, Leiden: Brill 1996.

5 Vgl. John MG Barclay, Jews in the Mediterranean Diaspora: Fom Alexander to Trajan (323 BCE-117 CE). Edinburgh: T\&T Clark 1996.
} 
die Joodse leefwyse volgens die Tora moet aanneem voordat hulle deel van die aanhangers van Christus kan wees nie? Impliseer die aanneming van nie-Jode in die Christusparty ook hulle toetrede tot die Joodse gemeenskap met die voorvereistes dat die mans besny moet word en almal binne die beskermmuur van die Tora moet leef? Kortom: is die geloof in Jesus Christus gebonde aan die Joodse kultuur waarbinne dit onstaan het?

Vir die beslegting van sulke vrae het Paulus en Barnabas van Antiogië af na Jerusalem gereis. In die brief aan die Galasiërs (2:1-10) vertel Paulus uitvoerig oor hierdie byeenkoms (vgl. ook Hand 15). Paulus was 'n goeie strateeg. Hy het een van sy bekeerlinge, Titus, wat 'n onbesnede Griek was, saamgeneem Jerusalem toe. Sy doel was duidelik: Titus was reeds gedoop en was reeds 'n Christen. Moes hy nou nog ook besny word en by implikasie volgens die wet leef? Die besluit van die apostels was duidelik. Titus is nie gedwing om homself te laat besny nie. Hy is as Griek en as nie-Jood, 'n broer in Christus en dus net so deel van die Christusfamilie as die Joodse volgelinge van Jesus. Hierdie word die spreekwoordelike 'deur' wat God vir die nie-Jode oopgemaak het. Hulle kan in die Christelike gemeentes opgeneem word sonder om eers Joods te word. Dit gaan alleen om die individu se geloof in en vertroue op die evangelie en nie om familiestatus, herkoms of groepsverband nie.

Hierdie grondbeginsel was een van die eerste en ook belangrikste beslissings in die geskiedenis van die Christendom. Dit beteken niks meer en niks minder as dat die vroegste kerkleiers binne die eerse twee dekades na die kruisiging van Jesus van Nasaret, besluit het dat daar net een kerk is waarbinne Jode en nie-Jode aanvaar word. By implikasie beteken dit dat daar waar die evangelie versprei word, diegene wat die evangelie in geloof aanvaar en hulle laat doop, wel gebonde is aan die evangelie, maar nie aan die kultuur van die sendelinge nie. Almal, sendeling en bekeerling, moet individueel net aan een voorwaarde voldoen: Geloof aan die evangelie oor Jesus Christus en lewe daarvolgens. Die gelowiges uit die sending van Barnabas en Paulus onder die nie-Jode is net so deel van Christus as die Jode wat in Jesus as Messias glo.

Benewens die aanvaarding van Titus as onbesnede broer in Christus, het Petrus, Johannes en Jakobus volgens Paulus se weergawe van die gebeure in Jerusalem oor 'n verdere saak ooreengekom. Omdat hulle aanvaar dat dit God is wat deur Paulus werk, aanvaar hulle ook Paulus se aanspraak dat God die verkondiging van die evangelie aan die onbesnedenes, m.a.w. aan die nie-Jode, aan hom, Paulus toevertrou het (Gal 2:7b). Hulle kom ook tot 'n vergelyk dat Petrus, Johannes en Jakobus na die Jode sal gaan en Paulus en Barnabas na die nie-Joodse nasies (Gal 2:9). Hoewel die besluit verder impliseer dat Paulus en Barnabas nie die taak het om terselfdertyd die evangelie aan die Jode te verkondig nie, het Paulus die reperkussies van die besluit m.i. eers deur bitter ervaring geleer. Hoewel Paulus op die Griekssprekende nie-Joodse nasies gefokus het, kon hy sy sending onder die nasies nie heeltemal onafhanklik van die Jode wat orals verstrooid in die antieke wêreld gewoon het, deurvoer nie. Verder wou en kon Paulus sy verkondiging van die evangelie aan die nasies nie losmaak van sy eie Joodse religieuse agtergrond nie.

\section{Probleme en teologiese beslissings in multi-etniese gemeentes}

In Jerusalem het dus 'n werksverdeling plaasgevind: Op die gemeenskaplike basis van die een evangelie is daar op 'n parallele sending besluit: apostels wat aan die Jode uitgestuur is en apostels wat na die ander nasies gegaan het. 
Antiogië: Wat is die werklike kriterium vir Christelike samehorigheid?

In Galasiërs 2:11-14 lees ons dat die eerste probleme van 'n gemengde gemeente in Antiogië in Sirië kop uitsteek. Die gemeente het uit Jode en nie-Jode bestaan wat aanvanklik weekliks saam geëet en saam nagmaal gevier het, Jode en nie-Jode. Selfs Petrus, wat eintlik die sendeling vir die Jode was, neem deel aan die verrigtinge. Toe daar egter Joodse aanhangers van Jesus uit Jerusalem op die toneel verskyn wat die wet meer nougeset wou toepas - nogal mense onder die invloed van Jesus van Nasaret se eie bloedbroer Jakobus - begin Petrus hom onttrek en sonder hom af van die samesyn met die nie-Joodse broers en susters in Christus. Petrus was 'n leiersfiguur en sy optrede dien as voorbeeld vir die ander Jode in die gemeente om dieselfde te doen. Selfs Barnabas, wat die gemeenskaplike opdrag saam met Paulus gehad het om die evangelie aan die nie-Jode te verkondig, onttrek hom van sy eie nie-Joodse gemeentelede en hou hom eenkant.

As apostel wat vir die evangelie aan die nasies verantwoordelik is, staan Paulus egter vas by die nie-Joodse gelowiges. Vir hom was dit van die begin af duidelik dat die geloof in Christus verbondenheid skep en nie etnisiteit nie. Dit gaan nie daaroor of iemand Joods of nie-Joods is nie. Hy berispe Petrus in die openbaar omdat hy, ten spyte daarvan dat hy die leier van die moedergemeente is, van die reguit pad van die evangelie afwyk.

Paulus se doen en late word deur sy eie teologiese insig in die veranderende situasie bepaal. Die maaltye in Antiogië het daaruit bestaan dat die gemeentelede gesamentlik een brood geëet en uit een kelk gedrink het. So het hulle die Here se dood en die betekenis daarvan herdenk. Hierdie samesyn was volgens Paulus toeganklik vir almal wat in Christus glo, deur die doop in Christus ingedoop is, en die Gees van Christus ontvang het. Of 'n persoon Joods is of nie - nie of hy of sy 'n baas of 'n bediende of ' $n$ man of ' $n$ vrou is - is nie ter sake nie. Etnisitiet, sosiale status en geslag het in die teenwoordigheid van die Here geen plek nie (Gal 3:28).

Al beroep kerkleiers hulle op die beste tradisie, kan hulle foute maak en van die reguit pad van die evangelie afwyk. Dit was immers Jesus van Nasaret se eie vroom broer, Jakobus, se volgelinge wat veroorsaak dat die gemeente in Antiogië in Joodse en nieJoodse kampe verdeel word. Dit was leiersfigure soos Petrus en Barnabas wat onder sosiale druk geswig het en die Joodse lede van die Christus party in Antiogië mislei het. Gelukkig was daar een kerkleier, Paulus, wat by die kern van die evangelie bly staan het.

\section{Listre: Die gebeure rondom Timoteus}

Sonder die wankelmoedige Barnabas vertrek Paulus hierna op sy missie om die evangelie aan die nie-Jode te gaan verkondig (Hand 15:36-41).

In Handelinge 16:1-6 lees ons van die gebeure rondom Timoteus. Die insident illustreer dat Paulus versigtig moes wees vir die sentimente van sy Joodse volksgenote in die suide van die Romeinse provinsie Galasië. Timoteus is tydens Barnabas en Paulus se eerste sendingreis in Listre deur Paulus gekersten (1 Kor 4:17) en waarskynlik ook gedoop. Hoewel Timoteus se pa 'n Griek was, was sy ma 'n Jodin. Sy het hom daarom ook die naam Timoteus - dit beteken 'Godvereerder' - gegee. Vir een of ander rede het sy ma hom nie laat besny nie. Waarskynlik omdat die gesin nie Joods geleef het nie, en sy Griekse pa bang was dat die ander seuns in die Griekse gimnasium met sy seun sou spot as hy saam met hulle kaal aan sport deelneem. Noudat Paulus vir Timoteus as medewerker saam op sy sendingreis wou neem, word dit 'n probleem vir sommige Joodse Christene, dat hy, anders as wat die norm was, as die seun van 'n Jodin, nie besny is nie. Paulus gaan 'n kompromis aan en besny Timoteus terwille van die Jode in Listre en Ikonium (Hand 16:3). Titus, 'n 
Griek, is kort tevore in Jerusalem nie gedwing om besny te word nie, want hy was reeds 'n Christen (Gal 2:3). Toe Timoteus aanvanklik op grond van Paulus se boodskap gedoop is, is hy nie nog besny ook nie, want om aan Christus te behoort, is die besnyding irrelevant (vgl. Gal 6:15). Sy ma was 'n Jodin en volgens gebruik moes sy Griekse pa eintlik besny word om in die Joodse familie van sy ma geïntegreer te kon word. Timoteus sou dan besny moes geword het. Paulus stel die saak reg deur Timoteus te besny, dit maak immers geen verskil aan Timoteus se status as gelowige nie, maar dit vergemalik Paulus en Timoteus se taak om die evangelie te verkondig, omdat dit die Jode se teenstand teen Paulus op hierdie wyse demp.

\section{Op pad na Asië: Wie doen waar sending?}

Paulus wou die evangelie aan die nie-Jode verkondig, maar 'n vyandige gesindheid van die plaaslike Jode sou sy taak bemoeilik. Waarom speel die plaaslike Jode so 'n belangrike rol? In al die stede aan die kus en langs die hoofpaaie was daar betreklik gevestigde Griekssprekende Joodse gemeenskappe. Wanneer Jode in 'n vreemde stad in die Meditereense gebied besoek agfelê het, was dit betreklik eenvoudig. Persone het gewoon op die Sabbat na die Joodse sinagoge gegaan waar hulle Griekssprekende Jode ontmoet het. Die Jode het die God van Abraham, Isak en Jakob as die enigste God vereer en hulle het die Griekse vertaling van die wet van Moses en die profete op die Sabbat in hulle sinagoges gelees. Hulle het sover moontlik volgens die wet geleef, hulle seuntjies besny en hulle dogters net toegelaat om te trou met Jode, of met mans wat bereid was om Jode te word en volgens die wet as deel van hulle Joodse familie te leef. Hierdie Jode in die verstrooiing het die natuurlike aanknopingspunt vir verspreiding van die blye boodskap gebied. Hulle vereer reeds slegs die God wat volgens Paulus se evangelie Jesus uit die dood opgewek het. Hulle ken die wet en die profete wat die evangelie oor Jesus as Seun van God aankondig (Rom 1:3). Sou Paulus egter begin om aan hierdie mense die evangelie te verkondig, neem hy Petrus, Johannes en Jakobus se taak oor en hou hy hom nie aan die oorspronklike ooreenkoms dat hy na die nasies sou gaan nie. Talle insidente uit die eerste jare van die sending toon dat Paulus moes leer om in sy spoor te trap om sodoende die ooreenkoms van Jerusalem te respekteer.

Na die insident rondom die besnyding van Timoteus het hy hom op die roete deur Klein-Asië bevind waar daar heelwat Jode in die stede gewoon het. Volgens Handelinge wou Paulus, Silas en Timoteus eintlik in die provinsie Asië die woord gaan verkondig, maar slaag nie daarin nie. Die outeur van Handelinge gee hiervoor 'n teologiese verklaring: hulle word deur die Heilige Gees verhinder (Hand 16:6). 'n Moontlike verklaring is dat Paulus waarskynlik vanaf Antiogië na Apamea en vandaar al met die Likusrivier af via Kolosse en Laodisië wou reis. Vandaar kon hy die Romeinse hoofweg al met die Meanderrivier langs deur Tralles en Magnesia volg om dan noord na Efese, die hoofstad van die Provinsie Asië, te draai. Paulus en sy medewerkers kon egter nie weswaarts beweeg nie, hulle word eers noord en toe noord-wes gedwing.

Agter die teologiese verklaring van Lukas dat die Heilige Gees vir Paulus gekeer het om na Asië te gaan, lê daar 'n belangrike historiese rede. ${ }^{6}$ Daar was 'n groot en invloedryke Joodse gemeenskap in Apamea. Die pad in die provinsie Asië in het Paulus geen ander

6 Vgl. Cilliers Breytenbach, Probable reasons for Paul's unfruitful missionary attempts in Asia Minor (a Note on Acts 16:6-7), in: Die Apostelgeschichte und die hellenistische Geschichtsschreibung. Festschrift für Eckhard Plümacher zu seinem 65. Geburtstag, hrsg. von Cilliers Breytenbach und Jens Schröter (AGJU 57), Leiden: Brill 2004, 157-169. 
keuse gelaat as om deur dié stad te reis nie. Die konflik rondom die besnydenis van Timoteus in Listre en omgewing en Paulus se boodskap dat die Grieke wat gedoop word, nie nodig het om hulle te laat besny en Joods te leef nie, het vir konflik in en om die sinagoges langs die hoofroete gesorg. Daar ontstaan later 'n ernstige konflik oor die noodsaaklikheid van die besnydenis vir bekeerlinge uit die nasies. Hierdie krisis noop Paulus om 'n brief aan die Galatiese Christene te skryf om hulle te verbied om hulle te laat besny en as ver-Joodse Christene in die sinagoge te laat opneem. Nog voordat die Galatiese konflik sy hoogtepunt bereik het, het die Jode in die suide van die provinsie Galasië waarskynlik die invloedryke Joodse gemeenskap in Apamea, ietwat verder langs die hoofroete, teen Paulus gewaarsku en daardeur verhinder dat hy via Apamea toegang tot Asië kon kry. Daar is genoeg rede om te vermoed dat die invloedryke Joodse gemeenskap in Apamea Paulus so te sê 'gehelp' het om by die ooreenkoms van Jerusalem te bly. Die pad van Antiogië na Kolosse loop oor Apamea. As Paulus hier gekeer is, kon hy nie verder na Laodisië en daarvandaan met die Meandervallei na Tralles, Magnesia en Efese reis nie. Eers twee tot drie jaar later kon sy medewerkers in die teenoorgestelde rigting vanuit Efese gemeentes in Laodisië en Kolosse stig. Die streek in sentraal Klein-Asië waar die Jode die sterkste invloed uitgeoefen het, die Frigiëse Pentapolis met stede soos Apamea, Eumeneia en Akomnië, kon eers in die derde eeu n.C. gekersten word.

Paulus het hom nie laat ontmoedig deur die mislukte poging om in die Romeinse provisie Asië die evangelie te verkondig nie. As Romeinse burger kon hy sy vrye toegang tot gebiede waar die Romeinse stadsreg geheers het, gebruik. Hy en Barnabas het reeds destyds gemeentes in die miltêre kolonies van Listre, Ikonium en Antiogië gestig. Hy, Silas en Timotheus gaan na die militêre kolonie Colonia (Iulia) Augusta Troadenis aan die noordooskus van Klein-Asië. Vandaar verlaat hulle Klein-Asië en gaan via Samotrake per skip na Neapolis en vandaar na die militêre Colonia (Iulia) Augusta Philippensis in Masedonië. Binne die stadgebied van elke kolonie het die Romeine net Romeinse godsdienste geduld. Alle ander godsdienste moes buite die stadsgrense beoefen word. Hier was dit vir Paulus baie makliker om die evangelie aan die nasies te verkondig sonder inmenging van 'n plaaslike sinagoge.

\section{Religieuse konflikte tydens die sending onder die nasies Filippi}

Paulus en sy reisgenote het vermoed dat daar 'n Joodse plek vir aanbidding buite die stadsgebied was. Hulle begin dus daar met hulle werk. Die eerste Christen in Filippi was 'n vrou met die naam Lidia. Sy was 'n godvresende mens, wat oorspronklik uit Tiatira in Lidië in Klein-Asië kom. Dié welgestelde vrou het purper verkoop, 'n artikel wat in sterk aanvraag was omdat die lede van die kolonie se regering purper tunicas gedra het. Lidia moes finansieel goed gedoen het, aangesien sy 'n eie huis in Filippi besit het. Sy en haar huisgesin is gedoop. Volgens die vertelling in Handelinge (16:15) het Lidia dadelik vir Paulus en sy reisgenote op die proef gestel. Sy praat ernstig met hulle en eis: "As ek volgens julle oordeel aan die Here glo (hulle moes so gedink het, want hulle het haar so pas gedoop), kom bly dan in my huis." Paulus, die Joodse sendeling vir die nasies, word nou uitgedaag om in die huis van 'n nie-Jodin te woon, aan haar tafel te sit en die kos wat sy voorberei het, te eet. Hy durf nie Joodse maatstawwe in die verhouding met die nie-Joodse Lidia aanlê nie. Dit sou hom, sy boodskap en sy werk ongeloofwaardig maak.

Maar daar is ook 'n ander kant: In die Romeinse kolonie in Filippi vestig Pau1us die eerste gemeente in Europa (Fi1 4:15,16; Hand 16:12-15). Volgens 1 Tess 2:2 het Paulus in Filippi 
baie gely en is hy mishandel. Waarskynlik is Paulus en Silas vervolg omdat hulle gebruike verkondig het wat nie vir die Romeine toelaatbaar was nie (Hand 16:20-21). Ten minste twee Romeine, Klemens (Fil 4:3) en die Romeinse gevangenisbewaarder, wat volgens Hand 16:2734 gedoop is, het by die gemeente aangesluit (in Romeinse kolonies was dit gebruiklik dat Romeine openbare poste beklee). In 'n latere brief wat Paulus aan die gemeente in Filippi skryf, doen hy 'n beroep op die gemeente om in ooreenstemming met die evangelie te leef en nie soos burgers in 'n kolonie nie (Fil 1:27). Hulle is nie deel van een van die stamme in die kolonie Filippi nie, maar het hulle burgerskap (politeuma) in die hemel (Fil 3:20) en behoort daarom aan 'n eie unieke stam. Paulus se vermaning kon die Romeinse burgers in die gemeente in konflik bring met die Romeinse adel wat die kolonie regeer het. Die Romeine het in die kolonie aan die tribus Voltina behoort. Sou hulle begin om slegs die een God van Israel te vereer, sou hulle die plaaslike Romeinse godsdiens en die aanbidding van die keiser se familie staak en sou hulle dan hul burgelike pligte verontagsaam.

\section{Thessalonike}

Van Filippi het Paulus-hulle na Tessalonike gegaan. Die stad is aan die Termise golf geleë op 'n besige kruising waar roetes van noord na suid en wes na oos ontmoet. As Griekse nedersetting het dit tot in die Romeinse tyd 'n selfregerende vrye stad gebly, maar natuurlik net in soverre Rome se imperiale belange nie bedreig is nie. Sou dit gebeur, sou die Romeinse prokonsul van die provinsie Masedonië, wat sy setel in Tessalonike gehad het, tussenbeide tree.

Paulus het 'n maand of meer in Tessalonike gewerk. Hy het wel ondersteuning van die gemeente in Filippi (Fil 4:15, 18) ontvang, maar nie van die gemeente in Tessalonike self nie. Filippi se ondersteuning help hom op sy voete. Toe dit met hom beter gaan, word hy selfversorgend - 'n goeie voorbeeld vir die gemeente in Tessalonike (1 Tess 4:9-12). Paulus, Timotheus en Silas het waarskynlik in die huis van een van die eerste bekeerlinge, 'n welgestelde Griek met die naam van Jason gebly. Vanuit Jason se huis het Paulus sy tentmakersberoep bedryf terwyl hy die boodskap aan die Grieke verkondig het (1 Tess 2:9). Hy het hulle vertel dat daar net een ware en lewendige God is, en dat dié sy Seun uit die dood uit opgewek het (1 Tess 1:9-10).

Sowel Paulus se lewenswyse as sy boodskap het hom in konflik met verskillende groepe in die stad gebring. Die eerste konflik kan waargeneem word in die vertelling in Hand 17:6-7: Omdat Paulus met sy tentmakerswerk kompetisie vir die ander handelaars op die stadsmark was, het hulle van die werklose leeglêers op die mark teen hom opgesweep. Die opgeruide skare soek hom in die huis van Jason, waar die gemeente gewoonlik vergader het. Hulle vind Paulus nie, maar slegs vir Jason en 'n paar ander gelowiges. Hulle word voor die stadsprefekte, die Grieke wat die vrye stad regeer, gesleep en aangekla.

Die aanklag is baie interessant: Paulus, Silas en Timoteus word daarvan beskuldig dat hulle oproermakers is wat verkondig dat daar 'n ander koning as die keiser is (Hand 17: 6-7). In 'n stad waar daar 'n tempel vir Julius Caesar was en die stadsbestuur reeds in Augustus se tyd munte geslaan het met die gestorwe Julius Caesar as god op die voorkant en Octavius op die agterkant, was dit natuurlik gevaarlik om hier te verkondig dat Jesus van Nasaret die Seun van die enigste lewende en ware God is en dat hy die mense uit die ellendes sou red (1 Tess 1:10). Paulus het Tessalonike in die tyd toe Klaudius regeer het, besoek. In daardie tyd kon enige inwoner van die stad op die plaaslike munte sien dat Augustus, Sabastos wat ook die titel 'redder' gehad het, op die voorkant van die munte as 
'god' genoem is. Klaudius is op die agterkant. ${ }^{7}$ Die implikasie is dat die regerende keiser Klaudius van goddelike afkoms is.

Van die keiser en sy goddelike voorvaders het die bevolking vrede en sekuritiet, pax et securitas verwag. Paulus kom met 'n ander boodskap waar ander lojaliteit vereis word. Die inwoners van Tessalonike moet hule bekeer en hul rûe op die afgodsbeelde, ook die van die keiser, draai. Die ware vrede en sekuriteit in die toekoms (1 Tess 5:3), moet van Jesus, die redder wat uit die dood opgewek is, van die Seun van die enigste lewende God (1 Thess 1:9-10) verwag word. Geen wonder dat Paulus van opstand beskuldig word en dat hy en sy medewerkers moes vlug nie. Sy gasheer Jason moes verantwoording voor die stadprefekte doen en borg betaal. Later skryf Paulus aan die Christene in Tessalonike dat hulle onder hulle eie mense gely het (1 Tess 2:15-16). 'n Mens kan nogtans die Griekse stadsbestuur se dilemma verstaan. Die stadprefekte moes sorg dat die onderliggende verset teen die verering van die keiser as filius divi en die afgestorwe keisers as gode wat in Paulus se boodskap opgesluit lê, nie konflik met Rome bring nie. As die keiser in Rome se plaaslike gesant hoor dat die stadsregering die boodskap duld, is daar seker moeilikheid. Die vrye polis (stad) is deel van die imperium en daarvan afhanklik. Gelukkig kon Paulus, Silas en Timoteus weg van die oproer na Berea vlug.

Die teologiese fondament van die evangelie wat Paulus aan die nasies verkondig, naamlik die een ware en lewendige God wat die gelowiges, ook die wat reeds ontslaap het, sal red soos hy reeds sy seun opgewek het, is deel van Paulus se erfenis as Jood. Dit is hierdie geloof, wat hom tydens sy sendingwerk aan die nasies in konflik met die Romeinse staatsideologie van die tyd bring .

\section{Korinte}

Na Tessalonike is Paulus se volgende sendingsentrum Korinte. In Atene was hy sonder sukses. Tydens die regeringstyd van Augustus het Korinte, wat die strategiese landstrook (genoem Istmus) tussen die vasteland en die Peleponesiese skiereiland beheer het, 'n ekonomiese opbloei beleef. Boonop is daar elke tweede jaar die grootste spele naas die Olimpiese spele aangebied. Die Isthmiese spele wat sport, musiek en teater ingesluit het, is op die vlakte noord van Korinte aangebied. Mense het van heinde en ver gestroom en in tydelike tentdorpe op die Istmus-landstrook gebly. Dit het verseker dat tentmakers soos Paulus werk gehad het.

Toe Paulus en Silas in Korinte aankom, was die Joodse sendelingpaar Akwilla en Priscilla reeds daar (Hand 18:2-3; 1 Kor 16:19). Oorspronklik het hulle van Pontus aan die Swartmeer gekom. Hulle was egter voordat hulle na Korinte verhuis het, deel van die Joodse volgelinge van Chr(e)stus in Rome wat in 49 n.C. deur keiser Klaudius uit die stad verban is. Dit is moontlik dat Paulus hulle in die sinagoge (volgens Handelinge 18:4-17 was daar 'n Joodse gemeente met hulle eie sinagoge) of op die markplein ontmoet het, omdat hulle soos hy tente gemaak en verkoop het. Akwilla was 'n welgestelde man en hulle het kort na hul aankoms uit Rome in 'n eie huis in Korinte gewoon. Paulus neem sy intrek by hulle, maak saam met hulle tente en sorg so vir homself. Dit was nooit nodig vir die gemeente in Korinte om hom finansieël te ondersteun nie.

Op die Sabbat verkondig Paulus die evangelie in die sinagoge (Hand 18:4-5). Hy beweer dat die gekruisigde Jesus die Messias is (1 Kor 1:18). Sowel die vertelling in Handelinge (18:4-5), asook Paulus se eie weergawe in 1 Kor 1:18 noem dat hy sy boodskap van die gekruisigde Jesus as die Messias aan die Jode en die Grieke gebring het. Vir die

Vgl. Helmut Koester, Paul and His World. Minneapolis: Fortress 2007, 43-45. 
Jode was die idee dat 'n mens, wat deur die Romeine as opstandeling aan 'n kruis gespyker is en toe gelos is om te sterf, die Messias kon wees, 'n struikelblok. Volgens die wet van Moses is iemand wat aan 'n houtpaal opgehang word, deur God vervloek (Deut 21:22-23; vgl. Gal 3:13). Vir die nasies, die nie-Jode, was die gedagte dat iemand wat so 'n jammerlike skanddood gesterf het daarna 'n reddersfiguur kon wees, gewoon onsin. Sommige glo egter. Daardeur word dit moontlik dat Paulus hier die fondament vir 'n gemeente kon lê (1 Kor 3:6-8). Sy eerste dopelinge was Stefanas en sy huisgesin (1 Kor 1:16; vgl. 16:15).

Maar hoe was dit moontlik dat Paulus met die Grieke praat terwyl hy in die sinagoge preek? Om dit te verstaan, is dit geweldig belangrik om te weet dat in die stede waar daar sterk Joodse sinagoges was, daar heelwat mense was wat deur die Joodse geloof met 'n enkele God, wetsgetroue leefwyse, periodieke feeste en weeklikse sabbastonderhouding beïnvloed en aangetrokke was. Indien sulke mense hulle laat besny het, is hulle as proseliete ten volle in die gemeenskap opgeneem. Daar was egter heelwat mense wat die God van Abraham, Isak en Jakob as die enigste God vereer het, en die wet ten dele gehou en aan die plaaslike sinagoge byeenkomste, feeste deelgeneem het sonder om hulle te laat besny en in alle opsigte Joods te lewe. Hierdie mense is die 'Godvresendes' genoem. Onder hulle was welgestelde nie-Jode wat bv. geld vir die sinagoge gegee het.

Een van hierdie welgestelde mense was 'n man met 'n Romeinse naam, Titius Justus. Toe Paulus die Jode nie kon oortuig dat Jesus die Messias is nie, verlaat hy die sinagoge en sit sy werk voort in die huis van hierdie godvresende man. Die huis was net langs die sinagoge (Hand 18:7). Vir die Joodse gemeenskap van Korinte was die verlies van Titius Justus as een van hulle welgestelde ondersteuners erg. Nog erger was die feit dat die leier van die sinagoge, die Joodse leiersfiguur wat vir die instandhouding van die sinagogegebou en die byeenkomste daarin verantwoordelik was, 'n ene Krispus, hom by Paulus en Titius Justus geskaar het (Hand 18:8). Krispus en nog 'n welaf man, Gaius word deur Paulus gedoop (1 Kor 1:14).

Tydens Paulus se werk van ongeveer een en 'n half jaar onstaan verskillende Christelike gemeentekringe wat weekliks in verskillende huise bymekaar kom: waarskynlik in die huise van Titius Justus, Akwilla en Priscilla (1 Kor 16:19-20) en die hele gemeente in die groot huis van Gaius (vgl. Rom 16:23). Hoewel die gemeente meerendeels uit nie-Jode bestaan het, het 'n paar prominente Jode en godvresendes by die gemeente aangesluit. Dit word duidelik dat die Jode in Korinte probleme met die optrede van Paulus gehad het. Toe die nuwe Romeinse prokosul, Iunius Annaeus Gallio in Julie 50/51 n.C. sy amp aanvaar, kla hulle Paulus aan. Hy moes voor die regterstoel, wat op 'n verhoog op die markplein gestaan het verskyn. Die aanklag is duidelik: Paulus oorreed die mense om God te vereer op 'n manier wat strydig met die Tora is (Hand 18:13). Omdat die aanklag betrekking het op die interne wetstoepassing van die Jode, het Gallio gemeen dat die saak nie sy aandag nodig het nie. Hy laat dit aan die Jode self oor. Die hoofaanklaer was ene Sostenes, die opvolger van Krispus as leier van die sinagoge. Toe die prokonsul die saak uitgooi, word Sostenes net daar op die forum deur die woedende skare aangerand (Hand 18:17). Die sinagoge het in elk geval een leier, Krispus en 'n invloedryke sympatiseerder, Gaius as gevolg van Paulus se sendingwerk verloor. ${ }^{8}$ Hierna verlaat Paulus Korinte.

Paulus propageer 'n Christendom waar die God van Israel as die einigste God, die Skepper en die Vader van Jesus Christus vereer word (1 Kor 8:6) sonder dat daar van die gelowiges uit die nasies verwag word om hulle te laat besny en volgens die wet te lewe. Dit

8 Daar bestaan die moontlikheid dat hierdie Sostenes sy amp as leier van die sinagoge verloor het en ook 'n Christen geword het, want 'n sekere Sostenes stuur saam met Paulus die eerste brief aan die Korintiërs (1:1). 
word noodwendig 'n vorm van godsdiens buite die grense van die plaaslike sinagoge. Die sinagoges het heelwat minder probleme met Jakobus en Petrus se sendingwerk gehad waarvolgens van die Jode verwag is om Jode te bly en Jesus as die Messias te aanvaar. Dan bly die Christene binne die wet en binne die sinagoge. Solank Paulus sy sending op plekke en gemeenskappe soos Filippi en Tessalonike toegespits het, waar daar min raakvlakke met die plaaslike sinagoges was, was die potensiaal vir konflik met die Jode gering. In stede soos Korinte en Efese, waar daar Grieke en groot getalle Jode gewoon het en sommige van die Grieke reeds die God van Israel vereer het, ontstaan daar mededinging en konfliksituasies tussen Paulus en die plaaslike Joodse gemeenskappe. In sulke gevalle het dit tot groot konflik gelei soos 'n mens ook uit die tweede brief aan die Korintiërs kan aflei.

\section{Paulus se evangelie, kultuur en lokaliteit}

Hierdie vinnige oorsig oor die vroegste jare in die Christelike sending en daaruitvoortspruitende gemeentevorming het getoon dat Christelike gemeenskappe op die grondbeginsel van die evangelie berus. Paulus was oortuig dat elke mens se individuele gelowige vertroue op die belofte dat God deur die dood en opstanding van Jesus Christus mense red, die toegang tot die Christelike geloofsgemeenkap vir elke individu afsonderlik verseker. Daarmee het Paulus 'n wesentlike bydrae tot die onstaan van die konsep van die individu as onafhanklike persoon gemaak. ${ }^{9}$ Die plaaslike gelowiges kom saam as 'n groep mense wat deur God geroep is en aan Christus behoort. Die Paulinese opvatting van gemeente word nie deur die institusionele raamwerk (bv. kerkverband) gedefinieer nie, maar deur gemeenskaplike geloof, doop, nagmaal en hoop. ${ }^{10}$

Slegs die geloof in Jesus as Messias en Here en die daaropvolgende doop en ontvangs van die Gees word kriterium of iemand aan Christus behoort, of soos Paulus dit stel (Gal 3:26; 4:6), hulle kinders van God is. Die Joodse moederkultuur, hoe belangrik dit ook vir die onstaan en formulering van die evangelie is, word oorskry. In die geval van Titus was dit onnodig dat hy deur die besnyding gejudaïseer moes word. Deur gelowiges as broers en susters van een familie met God as hulle Vader onafhanklik van volkse groeperinge te definieer, lê Paulus die grondslag vir ontwikkeling van die Christendom tot 'n transnasionale godsdiens. Noodgedwonge lei dit later tot 'n breuk met die Jodedom en word die Joodse Christene aan die einde van die eerste eeu uit die sinagoges verban. Dat die protestantisme, wat so baie van Paulus geleer het, van die begin van die reformasie af die Christendom in nuwe nasionaliteite herverdeel het, is verraad teenoor die apostel en sy evangelie as dié fondament van die Westerse kerk.

Vir die kinders van God is dit volgens Paulus nie ter sake of hulle Joods of Grieks, baas of bediende, manlik of vroulik is nie. Op plekke soos Antiogië in Sirië, waar gelowiges uit verskillende kulturele agtergronde vir gemeenskaplike maaltye, die nagmaal ingesluit, saamgekom het, geld hulle onderskeie leefwyse en gebruike, Joods of nie-Joods, vir hom nie as 'n kriterium vir hulle assosiasie met mekaar nie. Selfs Jesus se broer Jakobus se lewensgewoontes was geen rede om nie sosiaal en tydens die nagmaal met die bekeerlinge uit verskeie nasies te verkeer nie. Almal het op gelyke mate aan Christus behoort. Lidia in

$9 \quad$ Vgl. Paul Ricoeur, Paulus zum Apostel berufen. Verkündigung und Argumentation. Rezente Lektüren, Berliner Theologische Zeitschrift 27 (2010) vir die debat oor Paulus onder die filosowe sedert die werk van Taubes, Breton, Badiou en Agamben.

10 Vir die betekenis van Paulus opvatting vir die rol van die plaaslike gemeente vir die sendingteorie, vgl. Hauke Christiansen, Missionieren wie Paulus?, Roland Allens missionstheologische Rezeption des Paulus als Kritik an der neuzeitlichen Missionsbewegung, Neuendettelsau: Erlanger Verlag 2008, 132-135. 
Filippi illustreer hoe belangrik dit is vir diegene wat tot die Christendom toetree, dat hulle nie net religieus nie, maar ook sosiaal aanvaar moet word. Hulle moet in die nuwe familie van God opgeneem word. Die voordurende konflik met sy Joodse volksgenote wys hoe Paulus sy lewe op die spel geplaas het vir 'n nie-etniese fondament van sy gemeentes. Die Suid-Afrikaanse her-etnisering van dele van die Christendom en die gevolglike rassistiese verdeling van gemeentes en denominasies wys dat een van die kernelemente van Paulus se evangelie geïgnoreer is. Die fatale gevolge hiervan is alombekend.

Selfs wanneer kerkleiers soos in Jerusalem bymekaar kom, het besluite net invloed as daar mense soos Paulus is wat die besluite in die praktyk omsit. Omsigtigheid is natuurlik nodig. Die gebeure rondom Timoteus se besnyding wys dat ook Paulus die plaaslike omstandighede en gewoontes van ander in ag geneem het, maar slegs vir soverre die kern van die evangelie, naamlik die geloof in Christus alleen, nie daardeur gekompromiteer word nie. Sy stryd met die sinagogeleiers in Korinte kan as waarskuwing dien: Daar waar verskillende variante van 'n godsdiens om dieselfde mense, geboue en invloed kompeteer, is die konflikpotensiaal gewoonlik baie hoog.

Die wyse waarop Paulus die boodskap in Filippi en Tessalonike verkondig het, wys dat die geloof dat God sy Seun uit die dood opgewek het en die toekomstige redding van die mense van hom afhang, die Romeinse staatsideologie en die rol van die keiser gerelativeer het. Dit word duidelik dat die evangelie impliseer, dat gelowiges hulle rol binne die bestel van die stad en van die staat moes her-definieer.

Sedert die Romeinse ryk was daar 'n hele rits staatsvorme. Die Christendom het hulle almal oorleef. Binne die veranderende bestel van regeringsvorme en proses van transkulturasie, wat globaal tot die komplekse samestelling van plaaslike bevolkings lei, is dit vir die Christendom van kardinale belang om die geloofsbesluit van die individu, die nieetniese basis van die gemeente en die trans-nasionale aard van die Christendom voorop te stel. 